\title{
A VASÚTI SÍN FELÜLETI REPEDÉSTERJEDÉSÉNEK FELÜGYELETE
}

\section{MONITORING SYSTEM OF RAIL SURFACE CRACK PROPAGATION}

\author{
Nyikes Zoltán ${ }^{1}$, Tokody Dániel ${ }^{2}$, Kovács Tünde ${ }^{3}$ \\ 1,2Óbudai Egyetem, Biztonságtudományi Doktori Iskola, 1081 Budapest Népszínház \\ u.8.,nyikes.zoltan@phd.uni-obuda.hu,tokody.daniel@mav.hu
}

${ }^{3}$ Óbudai Egyetem, Bánki Donát Gépész és Biztonságtechnikai Mérnöki Kar, 1081

Budapest Népszínház u. 8., kovacs.tunde@bgk.uni-obuda.hu

\begin{abstract}
The industrial produced rails can include some failures without damaging. Even that if the rupture propagation reaches a critical size, it become of the breaking. The fracture mechanics suggest many different theories to determinate the fracture. The continuous monitoring of the rails surface state is necessary to assure the uninterrupted and safe transportation.
\end{abstract}

Keywords: crack, fracture toughness, monitoring system.

\section{Összefoglalás}

A nagy tömegben gyártott sín anyagok tartalmazhatnak hibákat, melyek még nem okoznak károsodást. Amennyiben azonban a keletkezett repedés növekedni kezd, elérheti azt a kritikus méretet mely már törést okoz. A törésmechanika számos elméletet dolgozott ki, mely méretezés során alapul szolgálhat. A repedések folyamatos ellenőrzése a sínpálya állapotfelügyelet tehát elengedhetetlen a folyamatos és biztonságos szállítás, közlekedés biztosításához.

Kulcsszavak: repedés, törési szívósság, felügyeleti rendszer.

\section{Bevezetés}

A vasút nagyon fontos infrastrukturális eleme egy országnak. A tömegközlekedés és az anyagmozgatás egyik igen hatékony eszköze. Ahogyan az már szinte a vasút születése óta ismert a sín és a vasúti kerék kapcsolata kulcskérdés. A sín-kerék kapcsolatban különböző károsodási formákkal találkozunk. A kopás és a sín felületének kifáradása, repedések keletkezése folyamatos a felület terhelése miatt. Ma már különböző minőségü síneket gyártanak, előfordul, hogy a felület szilárdságát hőkezeléssel javítják. A sínfelületen meglévő, vagy kialakuló repedések a folyamatos terhelés következtében növekedhetnek, majd törést okozhatnak. Ezek folyamatos ellenőrzése szükséges.

Jelenleg a vasúti sínek állapotfelügyeletét szemrevételezéssel végzik, mely igen lassú. A szemrevételezéssel felfedezett hibákat kézzel regisztrálják, majd ezeket az adatokat továbbítják. Az adatfeldolgozást szintén kézzel végzik.

Az Ipar 4.0 elvárásainak a digitális világ eszközeivel lehet megfelelni. Az anyagvizsgálat támogatására is ezeket az eszkö- 
zöket kell alkalmazni az adatok gyors és pontos feldolgozására és továbbítására.

\section{Repedések, anyagfolytonossági hibák}

Tökéletes, teljesen hibamentes anyagot az ipar nem tud gyártani tömegtermelésben. A sínek gyártása során is előfordulnak kisméretü hibák, repedések, melyek a terhelés hatására megindulhatnak és törést okozhatnak. Ezen kívül a sínek használata során nem csak a sín-kerék kapcsolat, de a nyílt terepen való alkalmazás miatt a felületet kőfelverődések és más mechanikus hatások is terhelhetik, melyek méretük és alakjuk szerint lehetnek repedések kiinduló helyei.

A törésmechanika méretezési alapot adhat a repedés méret és a terhelés közötti összefüggések megvilágításával. A kritikus repedés méret meghatározásának egyik módja a törésiszívósság összefüggés alkalmazásával lehetséges. A törési szívósság értéke függ az adott sín anyagától. Az (1) összefüggésből kiszámítható a veszélyes repedés mérete. A törési szívósság összefüggése, ahol a $(\mathrm{m})$ repedés félméret, $\sigma$ (MPa) terhelö feszültség.

$$
\left.K_{I C}=\sigma \cdot \sqrt{\pi \cdot a} \mid M P a \sqrt{m}\right]
$$

A feszültség az érintkező felület nagyságából és a terhelő erőből számítható. A maximális feszültség a vasúti kerék-sín érintkezés esetén a Hertz összefüggés alapján számítható [1]. Az összefüggés módosított alakja, az érintkezési felület a repedés méretével csökkentve (2) [2], ahol $\mathrm{F}$ a terhelés $(\mathrm{N})$, az érintkezési felület (ellipszis) $\left(\mathrm{mm}^{2}\right), 2 \mathrm{a}_{\mathrm{e}}$ az érintkező felület ellipszis nagy tengelye (mm), $2 b_{\mathrm{e}}$ érintkező felület ellipszis kis tengelye (mm), e sínen mérhető repedés felülete $\left[\mathrm{mm}^{2}\right]$ :

$$
\sigma=\frac{3}{2} \frac{F}{\left(\pi a_{e} b_{e}\right)-e}\left[\frac{N}{m^{2}}\right]
$$

A repedés ellipszis alakkal közelíthető. A kapcsolódó felület nagyságát a repedés felületének méretével kell csökkenteni, hogy a fellépő feszültséghez közelítő értéket kapjunk. $K_{I C}=41\lfloor M P a \sqrt{m}\rfloor$ értéke perlites sínacélra kísérleti úton meghatározott érték (irodalom alapján) [3].

Sín és a kerék érintkezési felülete ellipszis alakú, ennek nagy tengelye $2_{\mathrm{ae}}=13 \mathrm{~mm}$, kis tengelye $2_{\mathrm{be}}=10 \mathrm{~mm}$ területe $\mathrm{T}\left(\mathrm{mm}^{2}\right)$ :

$$
T=\pi a_{e} b_{e}=102,5\left[\mathrm{~mm}^{2}\right]
$$

Amennyiben nincs repedés a sín felületen akkor $\mathrm{e}=0 \mathrm{~mm}$ a terhelő feszültség (2) számítható, ha a terhelő erő $100 \mathrm{kN}$.

$$
\sigma=\frac{3}{2} \frac{F}{\left(\pi a_{e} b_{e}\right)-e}=1469,86\left[\frac{N}{\mathrm{~mm}^{2}}\right]
$$

A törési szívósság összefüggést (1) átrendezve kapjuk a megengedhető repedés méretet $2 \mathrm{a}-\mathrm{t}$ :

$$
2 a=2 \cdot \frac{\left(\frac{K_{I C}}{\sigma}\right)^{2}}{\pi}=0,4955[\mathrm{~mm}]
$$

$\mathrm{Az}$ adott terhelés mellett a repedés mérete nem lehet nagyobb 2a értéknél. A repedést szintén ellipszis geometriával lehet közelíteni, ennek a nagy tengelye 2a (mm). A repedés méretétől függően a Hertz feszültség növekedik és a károsodás mértéke is ezzel arányos. A vizuális vizsgálat során tehát olyan kamera szükséges, mely felbontását tekintve lehetővé teszi a hiba felismerését a számított mérettel összevethető tartományban.

\section{Adatok gyűjtése és elemzése}

Az alábbi részben a vasúti sin felületvizsgálatának informatikai biztosítása és annak vizsgálata kerül bemutatásra

\subsection{Primer adatok}

Az anyagvizsgálat esetén, a nagy menynyiségü, de „nyers” adatok keletkeznek. Ezeket a továbbiakban nevezzük primer adatoknak. [4] Ezeket az adatokat gyüjteni, tárolni és megfelelö csatornán továbbítani kell a további kiértékelés céljából. [5] 


\subsection{Szekunder adatok}

A vasúti sin állapotadatai mellett, a helykoordináták beazonosítása a primer adatokkal együtt kell tárolni és továbbítani. [6] Ezeket az adatokat a továbbiakban nevezzük szekunder adatoknak. Az adatok adatfúzió (data fusion) segítségével kerülnek tárolásra és továbbításra.

\subsection{Az adatok osztályozása és továb- bítása}

A vasúti pálya és az elemzése során keletkező adatok eltérőek. Annak fontossága és a hibák súlyossága okán három osztályba soroljuk, hogy annak prioritásának megfelelően kerüljön továbbításra és feldolgozásra.

\section{Kritikus adatok}

Ezek azok az adatok, amelyek olyan mérési adatok előzetesen feldolgozott eredményei, ami az előre meghatározott küszöbérték esetében a kiemelten kockázatos kategóriába esnek. A kritikus adatok azonnali továbbítása elengedhetetlenül szükséges, a valós idejü (real time) adatfel- dolgozás és a többi, az adott pályán közlekedő szerelvények biztonságos haladásához.

\section{Fontos adatok}

Ezek azok az adatok, amelyek olyan mérési adatok előzetesen feldolgozott eredményei, ami az előre meghatározott küszöbérték esetében a kockázatos kategóriába esnek. A fontos adatok azonnali továbbítása szükséges az adatfeldolgozás és a többi, az adott pályán közlekedő szerelvények biztonságos haladásához.

\section{Általános adatok}

Ezek azok az adatok, amelyek olyan diagnosztikai adatok, amelyek az előre meghatározott küszöbérték esetében az nem kockázatos kategóriába esnek. Ezeknek az adatoknak a kiértékelése a karbantartások tervezéshez szükségesek.

\section{Anyagvizsgálat eszközszükséglete}

Ahhoz, $200 \mathrm{Km} / \mathrm{h}$ sebesség esetén a vizsgáló berendezés el tudja végezni a vizs-

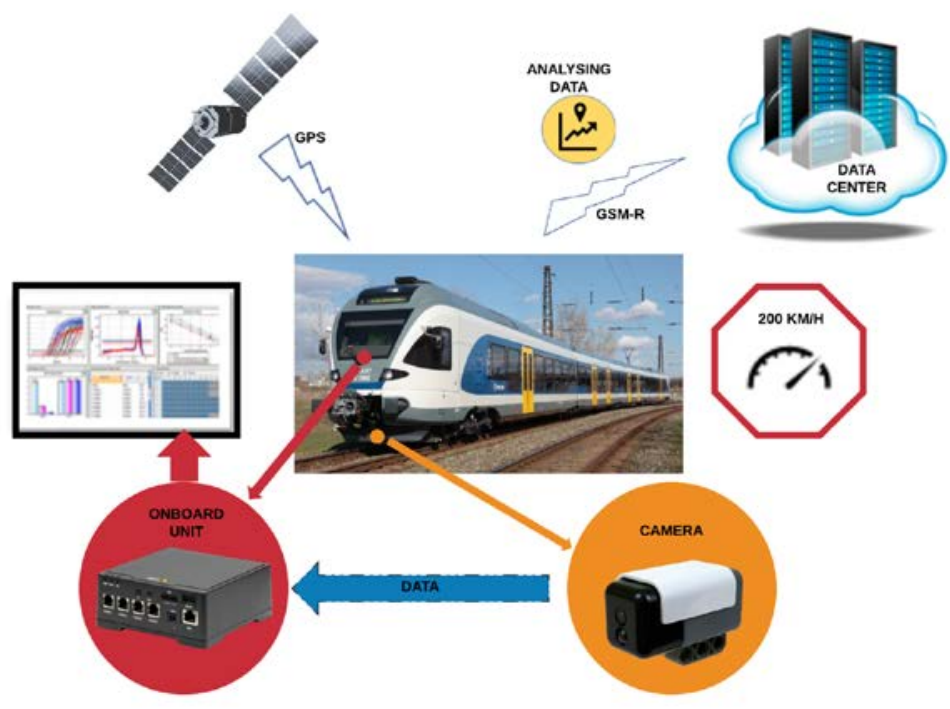

1. ábra. Az anyagvizsgálat adatelemzése és adattovábbítása 
gálatot, azaz folyamatos, kiváló minőségü és nagyfelbontású képet tudjon készíteni, ahhoz olyan kamerára van szükség, amely ezeket a kritériumokkal rendelkezik. Továbbá az adott kamera olyan gyorsaságú, azaz kép/másodperc rögzítési sebességgel kell, hogy rendelkezzen, amely esetében a folyamatos anyagvizsgálat biztosított.

Az adatok továbbításához nagy sebességü CAN BUS rendszerre van szükség, amely a gyors adattovábbításra képes adatvesztés nélkül, továbbá redundanciával is rendelkezik egy esetleges üzemzavar, vagy meghibásodás esetén.

$\mathrm{Az}$ adatok előzetes kiértékeléséhez gyors, nagy számítási kapacitással rendelkező fedélzeti számítógépre van szükség, amely a vasúti szerelvény felépítményébe integrálható. Zavarvédett a nagyfeszültségü elektromos hálózat elektromágneses sugárzásával és ellenáll a mechanikus hatásokkal szemben. Az adattárolási kapacitása a puffer tárolás tekintetében magas.

\section{Az infrastruktúra védelme}

Az elektronikus információvédelem biztosítása érdekében az átviteli út biztonsága, valamint a végpont és hálózatbiztonsági feltételek megteremtése elengedhetetlen annak érdekében, hogy a detektált és feldolgozott adatok a keletkezési helyükröl az adatközpontba, majd onnan az érintett szerelvények részére továbbításra kerüljenek. A fenti biztonsági szempontok figyelembevétele elengedhetetlenül szükséges, mivel kritikus infrastruktúráról beszélünk a vasút esetében. A jelenleg sorozatosan előforduló kritikus infrastruktúrák elleni kibertámadások rávilágítottak arra a tényre, hogy a kritikus infrastruktúrákat a kibertámadásokkal szemben is védelmezni kell. Ehhez olyan technikai és eljárásrendek alkalmazása szükséges, amelyek biztosítják az információk védelmét garantáló alapelveket.

\section{Következtetések}

A törési szívósság értékéből a kritikus repedés mérte meghatározható. A repedés mérete a számított értéket eléri vagy meghaladja, akkor várható, hogy a sín károsodik, mivel a Hertz feszültség extrém nagy értéket is elérhet. A repedések folyamatos felügyeletével elérhető, hogy megelőzhető legyen a katasztrofális károsodás.

\section{Szakirodalmi hivatkozások}

[1] L. Kazinczy: Wheel rail Hertzian contact investigation in case of vehicular train structure, BME 2017. Budapest, www.epa.uz.ua/00000/00028/00005/pdf/2.p df

[2] Z. Nyikes, D. Tokody, T. Kovács: In situ testing of rail damages in accordance with Industry $4.03^{\text {rd }}$ International Conference On Rheology and Modeling of Materials in Miskolc-Lillafüred, Hungary, 2-6 October, 2017. (megjelenés alatt)

[3] H. A. Aglan, M. Fateh: Fracture and Fatigue Crack Growth Analysis of Rail Steels, Journal of Mechanics of Materials and Structures Vol.2. N2, 2007. pp 336-346

[4] Mester, Gy., és mások: Adaptive Control of Robot Manipulators with Fuzzy Supervisor, Using Genetic Algorithms, Proceedings of International Conference on Recent Advances in Mechatronics, ICRAM'95, O. Kaynak (ed.), Vol. 2, pp. 661-666, ISBN 975-518063-X, Istanbul, 1995.

[5] Mester, Gy., és mások: Flexible Planetary Gear Drives in Robotics, Proceedings of the 1992 International Conference on Industrial Electronics, Control, Instrumentation and Automation - Robotics, CIM and Automation, Emerging Technologies, IEEE IECON '92, Vol. 2, pp. 646-649, ISBN 07803-0582-5, DOI: 10.1109/IECON. 1992.254556, San Diego, 1992.

[6] Iantovics, L.B.: A New Intelligent Mobile Multiagent System, in Proc. of the IEEE Int. W. on Soft Computing Applications (SOFA). Szeged-Hungary and Arad-Romania, IEEE Computer Society Press, IEEE Hungarian Section, 2005, pp.153-159. 